\title{
Geophysical Investigations and Aquifer Characteristics of the Benin Formation at Agbarho, Delta State, Nigeria
}

\author{
${ }^{* 1}$ UGBE, FC; ${ }^{2}$ UGBOME, DO; ${ }^{3}$ EMMANUEL, ED \\ ${ }^{* 1}$ Department of Geology, Delta State University Abraka, Delta State, Nigeria \\ ${ }^{2}$ Dan Drilling Services, Abraka, Delta State, Nigeria \\ ${ }^{3}$ Department of Physics, Delta State University, Abraka, Nigeria \\ *Corresponding Author Email: ugbefelix@yahoo.co.uk
}

\begin{abstract}
Groundwater investigations were carried out at Agbarho using geophysical survey method to delineate the aquifer and subsurface lithology. Three (3) vertical electrical sounding were conducted with a maximum current electrode spacing of $300 \mathrm{~m}$. The data acquired were subjected to partial curve matching and computer processing. The results delineated five geoelectric layers for the area, which include; topsoil, silty sand, silty clay, fine sand, medium grain sand and coarse sand. The Dar-Zarrouk parameter revealed an aquifer system that has a resistivity values ranging from 503.9-966.9 ohm-m, an average hydraulic conductivity of $7.73 \mathrm{~m} /$ day, and transmissivity in the range of $156.24-$ $181.44 \mathrm{~m}^{2} /$ day. The depth to the aquifer range from $13.2-42.7 \mathrm{~m}$ and the aquifer thickness is between $7-36.7 \mathrm{~m}$. Results from seven down-hole logs revealed the presence of silty sand, fine sand and fine-medium grained sand. The transmissivity values from pumping test range from $162.29-286.56 \mathrm{~m}^{2} /$ day and storativity is from $0.001-0.00838$. The aquifer is capable of yielding useful quantity of water to the wells and sustainable groundwater management plan can be develop for the area.
\end{abstract}

\section{DOI: $\underline{\text { https://dx.doi.org/10.4314/jasem.v25i6.8 }}$}

Copyright: Copyright $(0) 2021$ Ugbe et al. This is an open access article distributed under the Creative Commons Attribution License (CCL), which permits unrestricted use, distribution, and reproduction in any medium, provided the original work is properly cited.

Dates: Received: 20 March 2021; Revised: 27 April 2021; Accepted: 07 May 2021

Keywords: Aquifer Characteristics; Resistivity; Sombreiro-Warri Deltaic Plain; Agbarho; Niger delta

The exploration of groundwater is seldom carried out in rural communities because of their heavy dependence on surface water. However, in recent times surface water has been found to be highly contaminated as against what it was two decades ago. As a result of this, vigorous effort is now directed towards the exploration of groundwater as a better source of water supply to these rural communities. In borehole drilling, the need to determine suitable depth of penetration of aquifer for potable water resources has led to groundwater exploration by geophysical methods. This is because geophysical methods give better insight on the characteristics of the subsurface formation; thickness of the aquifer and suitable aquiferous zones required for groundwater exploitation. The electrical resistivity method have been employed successfully for groundwater exploration in the Niger Delta (Akpoborie and Aweto, 2011; Onu, 2003; Aweto and Akpoborie, 2014 and Oseji et al., 2005). Niger Delta region have been known for oil and gas exploration and exploitation for over four decades and this has resulted in the neglect of the agricultural sector for a long time. With the decline in oil and gas reserves and the drop in oil price, the government in her effort for economic diversification is trying to revitalize the agricultural sector to export our products to increase our foreign earnings. In furthering this agenda, rural communities are being opened up for massive agricultural practice. In doing this, special attention is being focused on groundwater resources for massive production of agricultural products. The study area is Agbarho in Delta State, which have been slated to host a massive agricultural project. Efobo et al., (2020) have earlier determined the groundwater flow direction and the hydrogeochemistry of this area. However, there is paucity of information on the subsurface lithology and aquifer characteristics of the study area. The main objective of this study is to address this information gap to enable effective groundwater resources for sustainable massive agricultural practice and domestic water supply within the area.

Location and Geology: The study area (Figure 1) is located between latitude $\left(5^{0} \quad 31 \mathrm{~N}-5^{0} \quad 37 \mathrm{~N}\right)$ and longitude ( $\left.5^{0} 48 \mathrm{E}-5^{0} 54 \mathrm{E}\right)$. It is part of the Niger Delta sedimentary basin. The Niger Delta sedimentary basin has been described by (Short and Stauble, 1997; Allen, 1965) as consisting of three distinct formations namely: The Benin Formation, the Agbada Formation, and the Akata Formation. The Benin Formation consists of sand and gravel, the Agbada Formation 
consists of alternating sand and shale, and the Akata Formation consist of marine shale. The study area is underlain by the Sombreiro-Warri Deltaic plain (SWDP), which is a continuation of the Benin Formation (Oomkens, 1974).

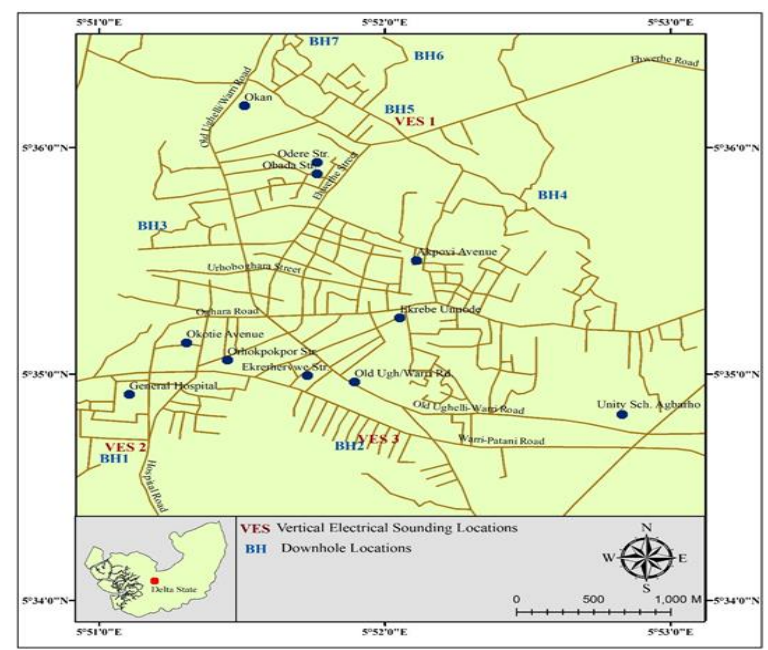

Fig 1. Map of the study area with VES and borehole locations (modified from Efobo et al., 2020).

\section{MATERIALS AND METHODS}

Electrical resistivity survey was used to determine the depth of aquifer occurrence and subsurface lithology. Three vertical electrical sounding were undertaken with the ABEM SAS 1000 Terrameter using the Schlumberger configuration with current electrode spacing $(\mathrm{AB} / 2)$ that range from $1 \mathrm{~m}$ to a maximum of $300 \mathrm{~m}$. The set up for Schlumberger configuration is a single line symmetrical order about a midpoint, where the central electrode is hammered into subsurface and two outer current electrodes and two inner electrodes were arranged in both left and right side. Current is send via Terrameter through the electrodes to the subsurface where data are collected in form of resistivity values in ohm-meter. The field data acquired were used to plot the sounding curves in a $\log -\log$ graph. The curves from the log-log graph were interpreted by partial curve matching techniques using master curves (Koefoed, 1979) and auxiliary point diagrams (Orellana and Mooney, 1966). The resistivity and thickness of the layer obtained from the partial curve matching were then subjected to computer iteration using the winResist software (Vander Velpen, 2004). Data from downhole log were obtained using the direct method of exploration carried out by drilling into the subsurface and using SAS 200 logging probe to log uncased hole in the area. Drill cuttings collected were labeled properly into a drill cutting sample box, which is subsequently used to prepare a geologic log for the drilled well. The geophysical logging was done using spontaneous potential (Sp) and resistivity logs. The Sp utilizes small electrical voltage produced from the boundaries of permeable strata (fine, medium and coarse sand). Pumping test were conducted on-site and the aquifer characteristics were determined using the CopperJacob (1946) straight-line method.

\section{RESULTS AND DISCUSSION}

Aquifer Delineation: Table 1 shows the inferred subsurface lithologies and their thicknesses at the three VES location. The model curves are shown in Figure 2, 3 and 4. The interpreted sounding curves revealed five geoelectric layers in VES 1 and VES 2 and six geoelectric layers in VES 3. The curve type include KHK (VES 1), KHA (VES 2), and HAKQ (VES 3), respectively.

Table 1. Result of geophysical interpretation

\begin{tabular}{lllllll}
\hline VES & Layers & Resistivity & Thickness & Depth & Curve type & Inferred lithology \\
\hline 1 & 1 & 265.9 & 0.6 & 0.6 & & Top soil \\
& 2 & 1733.8 & 1.5 & 2.1 & & Silty sand \\
& 3 & 164.4 & 3.8 & 5.9 & KHK & Fine sand \\
& 4 & 966.9 & 11.4 & 17.3 & & Coarse sand \\
& 5 & 118.7 &.-- &.-- & & \\
& 1 & 1058.6 & 0.6 & 0.6 & & Top soil \\
& 2 & 1953.6 & 0.7 & 1.3 & & Silty sand \\
& 3 & 247.7 & 4.7 & 6.0 & KHA & Fine sand \\
& 4 & 619.6 & 36.7 & 42.7 & & Medium sand \\
& 5 & 1427.5 &.-- &.-- & & \\
& 1 & 113.5 & 0.8 & 0.8 & & Top soil \\
& 2 & 28.4 & 0.6 & 1.4 & & Silty clay \\
& 3 & 84.2 & 0.7 & 2.2 & HAKQ & Silty clay \\
& 4 & 1037.2 & 4.1 & 6.2 & & Medium sand \\
& 5 & 503.9 & 7.0 & 13.2 & & Fine sand \\
& 6 & 84.2 &.-- &,-- & & \\
\hline
\end{tabular}

The geoelectric layers include the following: topsoil, silty sand, silty clay, fine sand, medium grain sand and coarse sand (Figure 5). The first layer has resistivity values that range from $113.5-1058.60 \mathrm{hm}-\mathrm{m}$ with a thickness $0.6-0.8 \mathrm{~m}$. This represents the topsoil. The second layer has resistivity values ranging from 28.4- 
$1953.60 h m-m$ with thickness of $0.6-1.5 \mathrm{~m}$. The deduced lithology is silty sand with the exception of VES 3, which is silty clay. The third layer has resistivity values ranging from 84.2-247.7ohm-m and a thickness of $0.7-4.7 \mathrm{~m}$. The inferred lithology is fine sand with the exception of VES 3, which is silty clay. The fourth layer has resistivity values ranging from 619.6-1037.2ohm-m with a thickness of 4.1-
$36.7 \mathrm{~m}$. The inferred lithology is medium sand with the exception of VES 1, which is coarse sand. The fifth layer has resistivity values that range from 118.7$1427.5 \mathrm{ohm}-\mathrm{m}$. The inferred lithology is fine sand. The depth to aquifer in the study area varies from $13.2 \mathrm{~m}$ (VES 3) through $17.3 \mathrm{~m}$ (VES1) to a maximum of 42.7m (VES 2). Table 2 shows the Dar Zarrouk parameters at Agbarho.
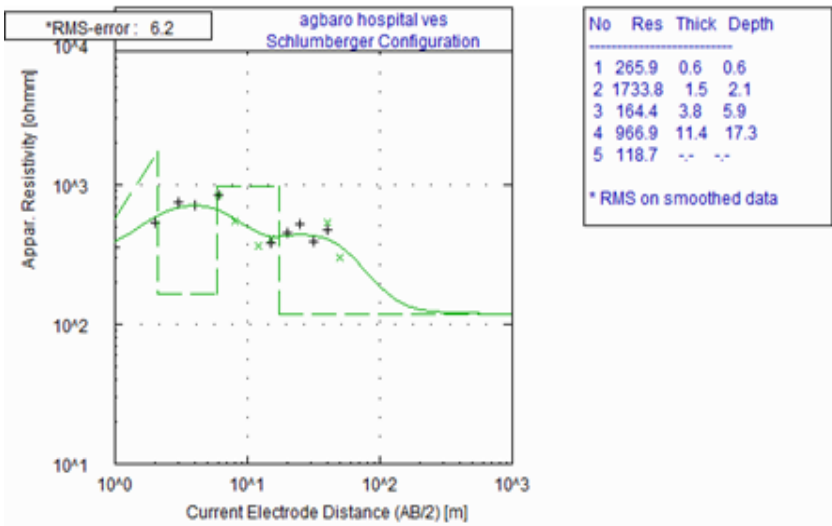

Fig 2. VES 1 curve for the study area
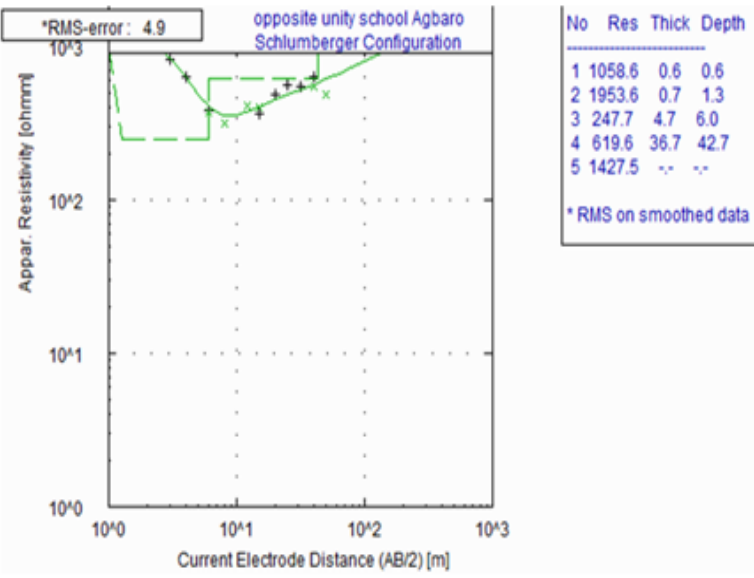

Fig 3. VES 2 curve for the study area
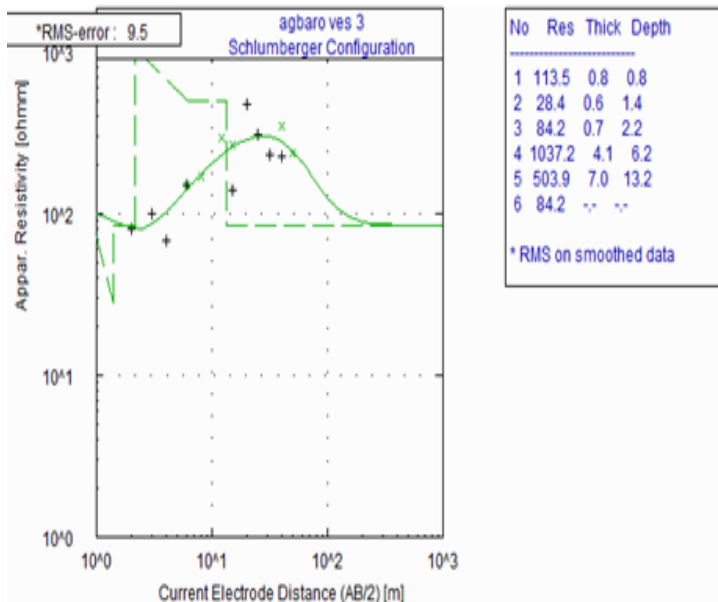

Fig 4. VES 3 curve for the study area.

UGBE, FC; UGBOME, DO; EMMANUEL, ED 


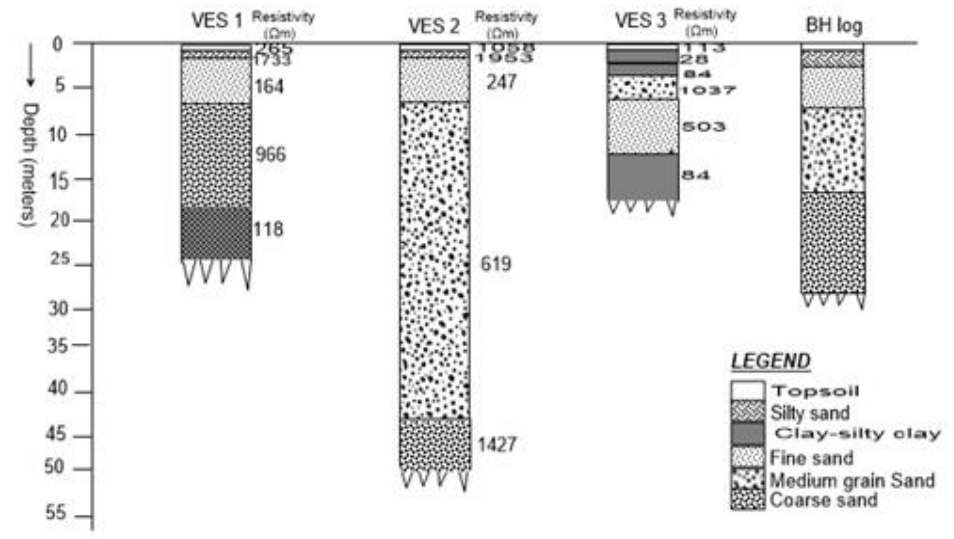

Fig 5. Geoelectric sections of the VES locations and lithology of borehole (BH).

Table 2. Dar Zarrouk Parameters at Agbarho

\begin{tabular}{|c|c|c|c|c|c|c|c|c|}
\hline VES & $\begin{array}{l}\text { Aquifer } \\
\text { Resistivity } \\
\rho(\Omega \mathrm{m})\end{array}$ & $\begin{array}{l}\text { Aquifer } \\
\text { Thickness } \\
\text { (h)m }\end{array}$ & $\begin{array}{l}\text { Aquifer } \\
\text { Conductivity } \\
\sigma=1 / \rho(\Omega \mathrm{m})^{-1}\end{array}$ & $\begin{array}{l}\text { Longitudinal } \\
\text { Conductance } \\
\mathrm{S}=\sigma \mathrm{h}\end{array}$ & $\begin{array}{l}\text { Transverse } \\
\text { Resistance } \\
\mathrm{R}=\mathrm{h} \rho\end{array}$ & $\begin{array}{l}\text { Hydraulic } \\
\text { conductivity } \\
\text { K (m/day) }\end{array}$ & $\begin{array}{l}\text { Transmissivity } \\
\mathbf{T}_{\mathbf{r}}=\mathbf{k h} \\
\left(\mathbf{m}^{2} / \text { day }\right)\end{array}$ & $\begin{array}{l}\text { Diagonostic } \\
\text { Parameters } \\
\text { ko }\end{array}$ \\
\hline 1 & 966.9 & 11.4 & 0.00103423 & 0.01179026 & 11022.66 & 5.18 & 156.24 & 59.08 \\
\hline 2 & 619.6 & 36.7 & 0.00161394 & 0.05923176 & 22739.32 & 8.08 & 181.44 & 296.82 \\
\hline 3 & 503.9 & 7 & 0.00198452 & 0.01389165 & 3527.3 & 9.94 & 160.44 & 69.61 \\
\hline
\end{tabular}

Lithology Evaluation: Drill cuttings from a borehole and seven down-hole logs within the study area are in agreement with the geophysical inferred lithology. An example of the down-hole log from the study area is shown in Figure 6. Results from interpreted down-hole log implies that the study area consist predominantly of silty sand, fine sand and fine-medium grained sands within the study area. The down-hole logs is useful in the evaluation of subsurface occurrence, thickness, and depth of the geologic sequence and geologic materials in an aquiferous horizon (Kambe et al., 2009, 2012).

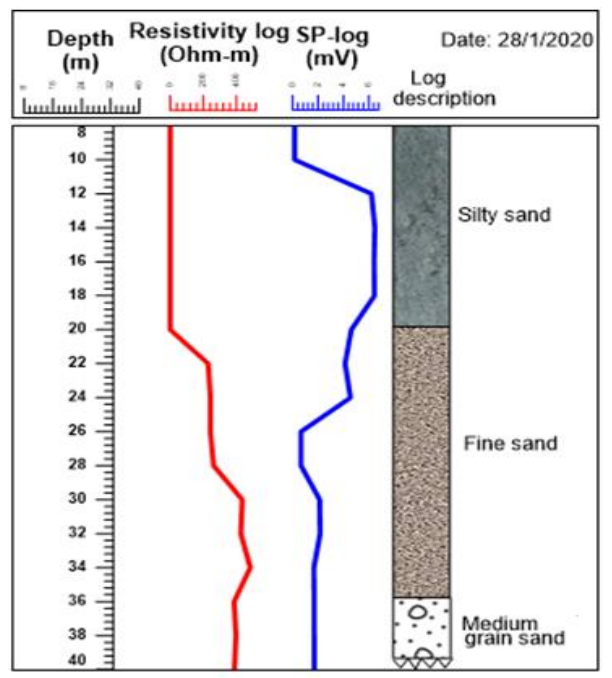

Fig 6. Down-hole log at Agbarho
Pump Test Analysis: Table 3 shows the results of the aquifer analysis. Data obtained from seven pumping test locations (Figure 1) were plotted on semilogarithmic paper to generate a time-drawdown graph used in estimating the transmissivity and storativity of the wells as shown in Figure 7(a-g).

The transmissivity value range from 162.29$286.56 \mathrm{~m}^{2} /$ day and storativity is from $0.001-0.00838$, respectively. The transmissivity values is somewhat similar to those estimated with the Dar Zarrouk presented in Table 2 .

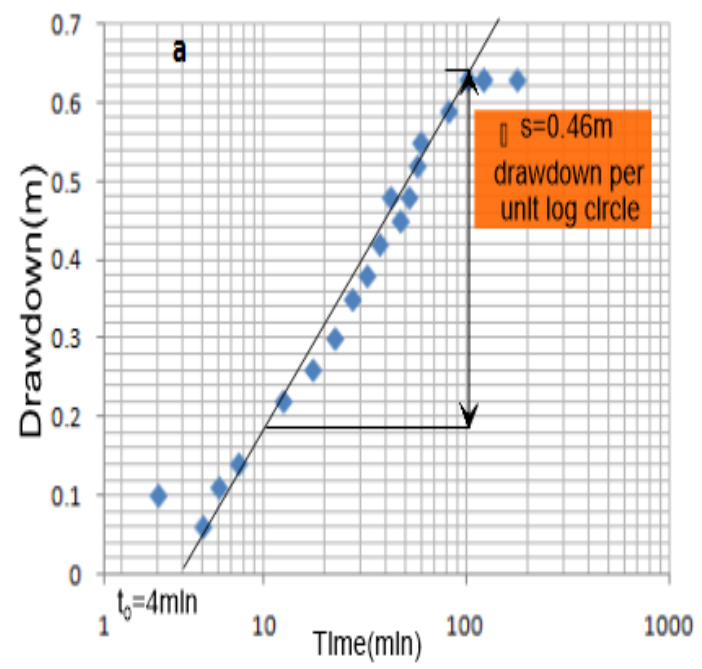



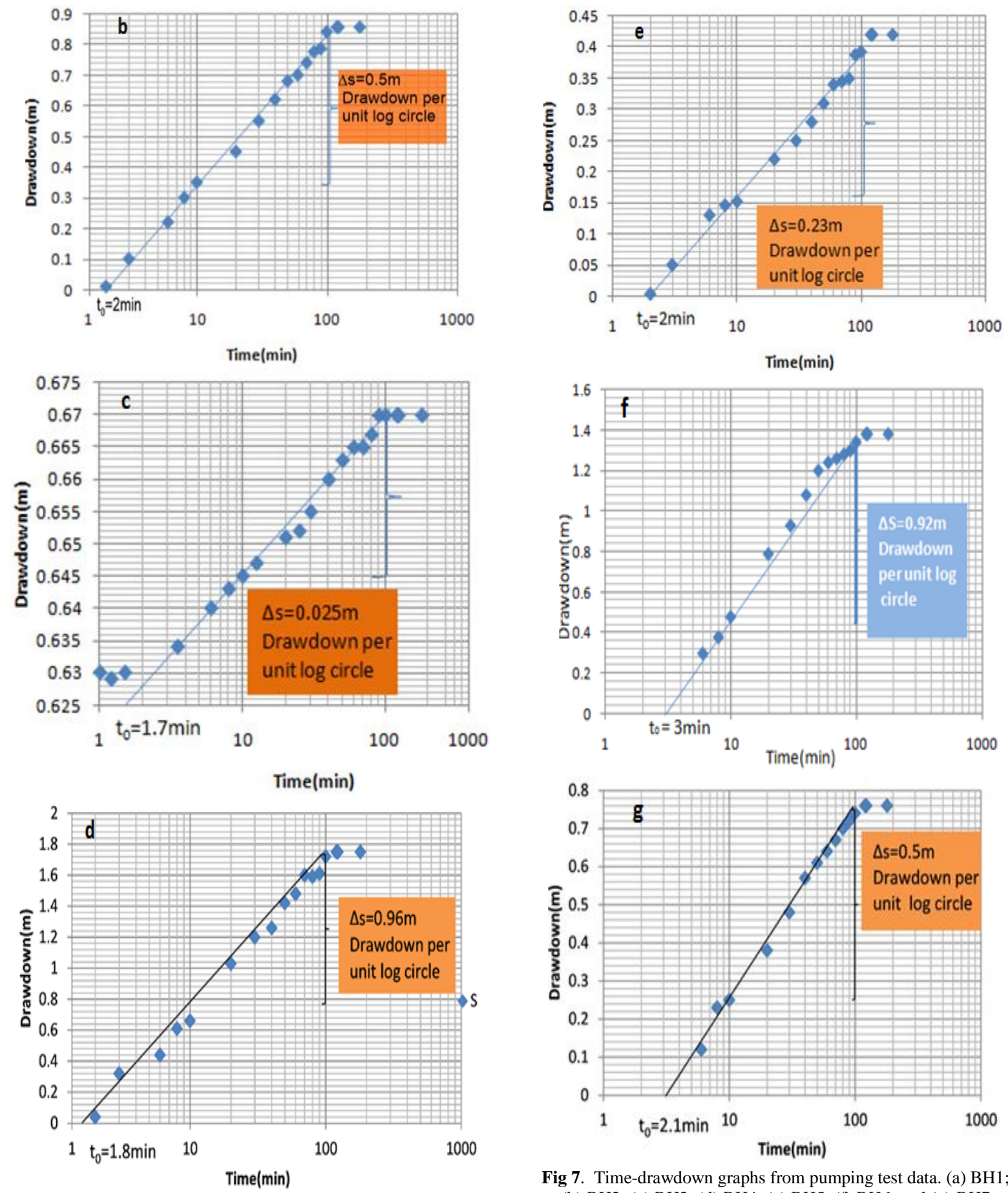

Fig 7. Time-drawdown graphs from pumping test data. (a) $\mathrm{BH} 1$ (b) $\mathrm{BH} 2$; (c) $\mathrm{BH} 3$; (d) $\mathrm{BH} 4$; (e) $\mathrm{BH} 5$; (f) $\mathrm{BH} 6$; and (g) BH7

Table 3. Aquifer Characteristics

\begin{tabular}{lll}
\hline $\begin{array}{l}\text { Boreholes } \\
(\mathbf{B H})\end{array}$ & $\begin{array}{l}\text { Transmissivity } \\
\left(\mathbf{m}^{2} / \mathbf{d a y}\right)\end{array}$ & Storativity \\
\hline BH1 & 286.56 & 0.0033 \\
BH2 & 273.31 & 0.002 \\
BH3 & 218.16 & 0.001 \\
BH4 & 187.34 & 0.00523 \\
BH5 & 162.29 & 0.00121 \\
BH6 & 188.99 & 0.00121 \\
BH7 & 218.88 & 0.00838 \\
\hline
\end{tabular}

Conclusion: This study has described the subsurface lithology and aquifer characteristics of the Agbarho area. Five geoelectric layers were delineated for the area. The geoelectric layers include topsoil, silty sand, silty clay, fine sand, medium grain sand and coarse sand. The depth to aquifer in the study area varies from $13.2-42.7 \mathrm{~m}$. The transmissivity derived from pumping test varies from 162.29-286.56 $\mathrm{m}^{2} /$ day. The high 
transmissivity value indicate a prolific aquifer for the study area, and this will guarantee adequate and sustainable water supply to drive the proposed agricultural project and for domestic purpose.

\section{REFERENCE}

Allen, JRL (1965). Late Quaternary Niger Delta and Adjacent Areas. Sed. Environ. Litho. 49(5):547600

Aweto, K; Akpoborie, IA (2011). Geo-electric and Hydrogeochemical Mapping of Quaternary Deposits at Orerokpe in the Western Niger Delta. J. Appl. Sci. Environl Manage. 15(2):351-359

Aweto, KE; Akpoborie, IA (2015). Estimating Aquifer Parameters with Geoelectric Soundings: Case Study from the Shallow Benin Formation at Orerokpe, Western Niger Delta, Nigeria. Brit. J. Appl. Sci. Technol 6(5): 486-496.

Efobo, O; Ugbe, FC; Akpoborie, IA (2020). Groundwater Conditions and Hydrogeochemistry of the Sombreiro-Warri Deltaic Plain Deposit (Shallow Benin Formation) in the Vicinity of Agbarho, Nigeria. J. Sci. Res. 12 (4):633-643.

Cooper, HH; Jacob, CE (1946). A generalized graphical method for evaluating formation constant and summarizing well field history. Amer. Geophy. Uni. 27 pp 526-534.

Kamble, RK; Panvalkar, GA; Bhowmick, S (2012). Electrical Resistivity Logging for Assessing Nature of Foundation at Kaiga Nuclear Power Plant. J. Ind. Geophys. Uni. 16(4): 161-167.
Kamble, RK; Rani, R.; Ghaosh, N; Panvalkar, GA (2009). Acoustic and Electrical Velocities of Foundation of Kakrapur Nuclear Plant. In: 33 Annual Convention and seminar on Exploration Geophysics, 4-6 February.

Koefoed, O (1979). Geosounding Principles I. Elsevier Scientific Publishing Comp. Amsterdam, $275 \mathrm{pp}$.

Onu, NN (2003). Estimate of the relative specific yield of aquifers from geo-electrical sounding data of the coastal plains of southeastern Nigeria. J. Technol. Educ. Nig., 8: 69-83.

Oomkens, E 1974. Lithofacies relations in the Late Quaternary Niger Delta Complex. Sed. 21:195222.

Orellana, E; Mooney, HM 1996. Master tables and curves for vertical electrical sounding over layered structures. Intersciencia, Madrid, 193pp.

Oseji, JO; Atakpo, EA; Okolie, EC (2005). Geoelectric investigation of the aquifer characteristics and groundwater potential in Kwale, Delta State, Nigeria. J. Appl. Sci. Environ. Manage. 9: 157-160.

Short, KC; Stauble, AJ (1967). Outline of geology of Niger Delta. Amer. Assoc. Petrol. Geol. Bull. 51:761-779.

Vander Velpen, BPA (2004). WinResist version 1.0. M.Sc Research project ITC, Daft, Netherland 